Check for updates

Cite this: RSC Adv., 2019, 9, 20677

\title{
Robust catalytically-activated LSM-BCZY-based composite steam electrodes for proton ceramic electrolysis cells $\dagger$
}

\begin{abstract}
Nuria Bausá (iD and José M. Serra (D) *
Backbone electrodes based on an electronic conductor and a protonic conductor show advantages for proton ceramic electrolyzer cells (PCECs). This work, aims to shed further light on the nature of the rate determining steps in the anode operation and improve the reaction rate in high steam pressure electrolysis mode by (i) adjusting their catalytic activity through electrode infiltration with catalytic electronic-conducting nanoparticles; and (ii) electrochemical activation of surface species by applying a net current through the electrode. A composite formed by $\mathrm{La}_{0.8} \mathrm{Sr}_{0.2} \mathrm{MnO}_{3-\delta}$ (LSM) and $\mathrm{BaCe}_{0.2} \mathrm{Zr}_{0.7} \mathrm{Y}_{0.1} \mathrm{O}_{3-\delta}$ (BCZY27) was deposited on proton-conducting BCZY27 electrolytes and studied in symmetrical cells to investigate the anode microstructure and electrochemical performance. Electrochemical impedance spectroscopy (EIS) measurements were performed in the $800-500{ }^{\circ} \mathrm{C}$ range under 3 bar of pressure of wet air (75\% of steam). LSM/BCZY27 50/50 vol\% showed the best performance with an electrode polarization resistance $\left(R_{\mathrm{p}}\right)$ of $6.04 \Omega \mathrm{cm}^{2}$ at $700{ }^{\circ} \mathrm{C}$ and high steam pressure (0.75 bar of air and 2.25 bar of steam) whereas LSM/BCZY27 60/40 vol\% presented a $R_{\mathrm{p}}$ of 18.9 $\Omega \mathrm{cm}^{2}$. The backbone electrodes were infiltrated using aqueous solutions of metal precursors to boost the electrocatalytic activity towards water splitting and oxygen evolution. The infiltrated cells were fired at $850{ }^{\circ} \mathrm{C}$ for $2 \mathrm{~h}$ to obtain the desired crystalline nanoparticles $\left(\operatorname{Pr}_{6} \mathrm{O}_{11}, \mathrm{CeO}_{2}, \mathrm{ZrO}_{2}\right.$ and $\left.\operatorname{Pr}_{6} \mathrm{O}_{11}-\mathrm{CeO}_{2}\right)$ and electrochemically tested under high steam pressures and bias currents to investigate the influence of catalytic activation on surface exchange kinetics. Among the tested catalysts, the lowest electrode polarization resistances $\left(<0.2 \Omega \mathrm{cm}^{2}\right)$ were reached for the $\operatorname{Pr}_{6} \mathrm{O}_{11}, \mathrm{CeO}_{2}$ and $\operatorname{Pr}_{6} \mathrm{O}_{11}-\mathrm{CeO}_{2}$ catalysts at $700{ }^{\circ} \mathrm{C}$ by applying current densities ranging from 1.57 to $14.15 \mathrm{~mA} \mathrm{~cm}{ }^{-2}$, and the $\mathrm{Pr}_{6} \mathrm{O}_{11}-\mathrm{CeO}_{2}-$ activated LSM/BCZY27 electrode exhibited the best performance. Finally, the effect of $\mathrm{pO}_{2}$ and $p \mathrm{H}_{2} \mathrm{O}$ was investigated aiming to characterize the rate limiting processes in the electrodes.
\end{abstract}

Received 28th May 2019

Accepted 12th June 2019

DOI: $10.1039 / c 9 r a 04044 g$

rsc.li/rsc-advances

\section{Introduction}

Proton conducting ceramics have attracted much attention due to their applications in energy conversion, hydrogen sensing and separation, and chemical synthesis. ${ }^{1-12}$ For proton ceramic fuel cells (PCFCs), the cathode is a challenge, because it is difficult to find suitable materials with good mixed p-type electronic and protonic conductivity. ${ }^{13,14}$ Recent work on PCFC cathode performance has shown that the use of a ceramic-ceramic (cer-cer) composite having a proton conducting phase (electrolyte) and an electronically conducting phase with respect to the cathode material, enables major improvement of the electrochemical performance, ascribed to extension of the three phase boundary (TPB) area

Instituto de Tecnología Química (Universitat Politècnica de València - Consejo Superior de Investigaciones Cientificas), Av. Naranjos s/n, E-46022 Valencia, Spain. E-mail: jmserra@itq.upv.es

$\dagger$ Electronic supplementary information (ESI) available. See DOI: 10.1039/c9ra04044g from the electrode-electrolyte interface to the whole cathode thickness. ${ }^{15-17}$

In proton ceramic electrolysis cells (PCECs), a similar challenge is encountered for the development of the anode and additionally the electrode should be effective and stable in high steam environments. The porous anode of the cell has the function to (1) catalyse the dissociation of $\mathrm{H}_{2} \mathrm{O}$ to protons and molecular oxygen and (2) collect the electronic current generated along the cell. A careful electrode design is required to (i) avoid overpotentials/ohmic losses resulting from limitations in steam gas transport; (ii) promote the fast removal of the produced oxygen, which can induce electrode delamination; (iii) reach sufficient protonic transport level to extend triplephase-boundary (TPB) regions; and (iv) warrant sufficient electronic conduction in the whole electrode volume. As a consequence, several properties must be combined in composite electrodes comprising at least two different materials with bulk transport (at least protonic and electronic), appropriate porous microstructure for gas transport, and tailored electrocatalytic surface properties. In order to promote fast oxygen removal 
against the inwards flux of steam, oxide-ion transport can be included in the electrode material, permitting oxygen diffusion through bulk, leaving the pore system mainly for the gaseous steam diffusion. Materials for electrodes are typically perovskites containing $\mathrm{Ba}$ and/or rare earths on the A site and transition metals (notably $\mathrm{Cr}, \mathrm{Mn}, \mathrm{Fe}, \mathrm{Co}$ ) on the B site. ${ }^{18}$

The requirements for PCEC anodes are good transport properties, high catalytic activities and long-term chemical stability in steam electrolysis conditions (high steam pressures). Moreover, the material for this steam electrode, specifically, must exhibit low activation, ohmic and mass transport polarizations. The decrease in area specific resistance (ASR) is a crucial point in PCEC efficiency and economics.

Ceramic-ceramic (cer-cer) composites based on mixtures of different kinds of conducting materials, as an electronic and a protonic conductor, have demonstrated good performances in PCFC electrodes operating at intermediate temperatures (500$\left.700{ }^{\circ} \mathrm{C}\right) .{ }^{19} \mathrm{~A}$ pure electronic conductor such as $\mathrm{La}_{0.8} \mathrm{Sr}_{0.2} \mathrm{MnO}_{3-\delta}$ (LSM), is a promising electrode material for high-temperature due to its excellent stability, possesses insignificant oxide-ion conductivity and the risk of electrode delamination is minimized..$^{20-23}$

In this work, the advantages for composite electrodes based on a protonic conductor $\mathrm{BaCe}_{0.2} \mathrm{Zr}_{0.7} \mathrm{Y}_{0.1} \mathrm{O}_{3-\delta}(\mathrm{BCZY} 27)^{24-26}$ and an electronic conductor (LSM) are utilized. ${ }^{20}$ The operation of LSM/BCZY27 composite anode is limited by surface-related processes, as inferred from the low frequencies of these processes characterized by electrochemical impedance spectroscopy (EIS) spectrum. ${ }^{27}$ Therefore, the use of a proper catalyst is decisive for an efficient anode development. The dispersion of catalytic nanoparticles on the electrode surface may induce two effects: (i) new oxide-ion conduction pathways are generated on the electrode surface; and (ii) the overall catalytic processes are improved, thanks to the higher surface area and the higher intrinsic redox activity of the redox sites of the chosen catalytic species. Following previous studies on the modification of electrodes by infiltration with nanoparticles, ${ }^{28-31}$ the present work focuses on enhancing the electrochemical performance of LSM/BCZY27 by activating the porous backbone electrode with different catalysts, $\operatorname{Pr}_{6} \mathrm{O}_{11}$, $\mathrm{CeO}_{2}, \mathrm{ZrO}_{2}$ and $\mathrm{Pr}_{6} \mathrm{O}_{11}-\mathrm{CeO}_{2}$ on both sides.

\section{Experimental}

The composite anode based on an electronic conductor $\mathrm{La}_{0.8^{-}}$ $\mathrm{Sr}_{0.2} \mathrm{MnO}_{3-\delta}$ (LSM) and a protonic conductor $\mathrm{BaCe}_{0.2} \mathrm{Zr}_{0.7} \mathrm{Y}_{0.1^{-}}$ $\mathrm{O}_{3-\delta}$ (BCZY27) have shown advantages for PCFCs based on BCZY27 electrolytes. ${ }^{20,32}$ Commercial $\mathrm{BaCe}_{0.2} \mathrm{Zr}_{0.7} \mathrm{Y}_{0.1} \mathrm{O}_{3-\delta}$ (BCZY27) powder, purchased from CerPoTech, was calcined at $1100{ }^{\circ} \mathrm{C}$ for $6 \mathrm{~h}$ and ball-milled for $10 \mathrm{~h}$ in acetone. $\mathrm{La}_{0.8} \mathrm{Sr}_{0.2^{-}}$ $\mathrm{MnO}_{3-\delta}$ (LSM) powder was supplied from Marion Technologies. Powders were ball-milled for $16 \mathrm{~h}$ in acetone to obtain similar grain sizes.

The studied cer-cer compositions were prepared by mixing LSM and BCZY27 powders in different volume in an agate mortar. Then, the compatibility of the electrode with the electrolyte material was tested by using X-ray diffraction (XRD) analysis after sintering together at $1100{ }^{\circ} \mathrm{C}$ for $5 \mathrm{~h}$. XRD measurements were recorded in the $2 \theta$ range from 20 to $70^{\circ}$ on a CubiX FAST equipment using $\mathrm{CuK} \alpha_{1,2}$ radiation and an $\mathrm{X}$ 'Celerator detector in Bragg-Brentano geometry. Patterns were analyzed using X'Pert High Score Plus software (PANalytical).

Electrochemical measurements were performed by using a dense $\mathrm{BaCe}_{0.2} \mathrm{Zr}_{0.7} \mathrm{Y}_{0.1} \mathrm{O}_{3-\delta}$ (BCZY27) electrolyte by mixing the BCZY27 powder with $1 \mathrm{wt} \% \mathrm{ZnO}$ (Sigma Aldrich) as sintering aid $^{33,34}$ and ball-milled for $16 \mathrm{~h}$ in acetone. Afterwards, the electrolyte was uniaxially pressed at $\sim 120 \mathrm{MPa}$ and calcined in air at $1550{ }^{\circ} \mathrm{C}$ for $12 \mathrm{~h}$ with a constant heating rate of $2{ }^{\circ} \mathrm{C} \min ^{-1}$.

Porous $30 \mu \mathrm{m}$ electrodes were obtained by screen painting the LSM/BCZY27 ink on both sides of the BCZY electrolyte and fired at $1100{ }^{\circ} \mathrm{C}$ for 2 hours. The inks were prepared by mixing the LSM/BCZY27 with a $6 \mathrm{wt} \%$ ethylcellulose-terpineol solution in a three roll mill. The final symmetrical cell was $15 \mathrm{~mm}$ in diameter, while the anodes were $9 \mathrm{~mm}$ in diameter approximately.

Furthermore, different $2 \mathrm{M}$ solutions (ethanol-water) with adjusted surface tension were prepared with the different $\mathrm{Pr}$, $\mathrm{Ce}$, and $\mathrm{Zr}$ nitrate precursors; $\mathrm{Pr}\left(\mathrm{NO}_{3}\right)_{3} \cdot 6 \mathrm{H}_{2} \mathrm{O}, \mathrm{Ce}\left(\mathrm{NO}_{3}\right)_{3} \cdot 6 \mathrm{H}_{2} \mathrm{O}$ and $\mathrm{Zr}\left(\mathrm{NO}_{3}\right)_{2} \cdot x \mathrm{H}_{2} \mathrm{O}$, respectively. The solution was dropped onto the whole electrode surface. The catalyst loading was around $5 \mathrm{wt} \%$. The particles were spread along the composite backbone surface, forming different infiltrated oxide catalysts after calcination at $850{ }^{\circ} \mathrm{C}$ for 2 hours. Electrochemical performance of the different LSM/BCZY27 composites was tested by electrochemical impedance spectroscopy (EIS) measured in two-point configuration with platinum current collector meshes (see ESI Fig. S1a $\dagger$ ). Input signal was $0 \mathrm{~V}$ DC to $20 \mathrm{mV}$ AC in the $0.01-1 \times 10^{6} \mathrm{~Hz}$ frequency range (Autolab PGSTAT128N potentiostat equipped with a FRA32M module for impedance analysis). EIS measurements were performed in the $800-500{ }^{\circ} \mathrm{C}$ range under 3 bar total pressure ( $p$ Air $=0.75$ bar and $p \mathrm{H}_{2} \mathrm{O}=$ 2.75 bar). In addition, $p \mathrm{H}_{2} \mathrm{O}$ was varied in the range 1.14-4.84 bar.

The three-wire configuration (ESI Fig. S1b $\dagger$ ) is used to analyze the EIS under the applied current (bias) and it has one working electrode on the anode, with the corresponding sensing contact on the electrolyte and the opposite sensing and working electrodes on the other electrode. With this configuration, only one anode contribution is measured and it is possible to study the effect when a net current is applied. A range of currents $\left(1.57-14.15 \mathrm{~mA} \mathrm{~cm}{ }^{-2}\right)$ is applied in this study.

The microstructure was investigated using a field emission scanning electron microscopy (FE-SEM) (Zeiss Ultra 55), and the elemental analysis was carried out with energy-dispersive X-ray spectroscopy (EDS) (INCA, Oxford).

\section{Results and discussion}

\subsection{Preparation and characterization of LSM/BCZY27 electrodes}

In first place, the compatibility of the selected anode material with the BCZY27 electrolyte was checked by means of XRD upon 
heat treatment. ESI Fig. S2 $\uparrow$ shows the XRD patterns of the possible electrode material, LSM, which is mixed with the electrolyte material, BCZY27, and they were sintered at $1100{ }^{\circ} \mathrm{C}$ for $2 \mathrm{~h}$. Furthermore, different reference patterns and the single powders patterns are also depicted for comparison. LSM and BCZY27 materials are compatible, with no extra peaks after the sintering process.

The microstructure of the different powders from SEM images is shown in ESI Fig. S3. $\uparrow$ The crystal size of the BCZY27 was very small (below $10 \mathrm{~nm}$ ) and it was comparable to the LSM size.

The stability of the BCZY27 and LSM was checked under 3 bar total pressure ( $p$ Air $=0.75$ bar and $p \mathrm{H}_{2} \mathrm{O}=2.75$ bar) at $700{ }^{\circ} \mathrm{C}$ for $72 \mathrm{~h}$. From the obtained XRD patterns and SEM images (Fig. 1a-c), it can be inferred that both materials remain stable, with no extra diffraction peaks related to secondary phases.

In SEM images, Fig. $1 \mathrm{~b}$ and d, it is possible to see that both materials are stable under electrolysis operating conditions, with no degradations in the microstructure. In summary, it was proved that BCZY27 electrolyte material and LSM electrode material were stable under realistic conditions, high temperature and high steam pressure.

After the anode material was selected, the LSM/BCZY27 composite was optimized by preparing symmetrical cells changing the volume\% of each phase and the electrochemical performance was tested by electrochemical impedance spectroscopy (EIS) measurements in two-point configuration with platinum current collector meshes.

The temperature dependence of $R_{\mathrm{p}}$ values for 2 different electrodes was measured under a total pressure of 3 bar $(0.75$ bar of air and 2.25 bar of steam) with different composite compositions, i.e., LSM/BCZY27 60/40 and 50/50 vol\%. The electrode polarization resistance is defined as the sum of electrode contributions at different frequencies. The behaviour of both electrodes was similar and the best performance was observed for the 50/50 vol\% composite (Fig. 2). Impedance spectra can be fitted by using equivalents circuits, slightly different for each composition. Specifically, the equivalent circuit $\mathrm{LR}_{0}\left(R_{\mathrm{HF}} \mathrm{CPE}_{\mathrm{HF}}\right)\left(R_{\mathrm{LF}} \mathrm{CPE}_{\mathrm{LF}}\right)\left(R_{\mathrm{LLF}} \mathrm{CPE}_{\mathrm{LLF}}\right)$ was employed for the LSM/BCZY27 60/40 vol\% whereas $\mathrm{LR}_{0}\left(R_{\mathrm{HF}} \mathrm{CPE}_{\mathrm{HF}}\right)\left(R_{\mathrm{LF}} \mathrm{CPE} / \mathrm{LF}\right)$ was used for the LSM/BCZY27 50/50 vol\% at different characteristic frequencies, high frequencies ( $\mathrm{HF}, 0.1-4 \mathrm{kHz}$ ), low frequencies (LF, 1-5 Hz) and low-low frequencies (LLF, 0.02-1 $\mathrm{Hz}$ ). The high activation energy $\left(E_{\mathrm{a}}\right)$ values observed for $R_{\mathrm{p}}$ of both electrodes in Fig. 2a (1.41-1.98 eV) indicate that proton conduction is not the rate-limiting step, since the activation energy for proton migration usually ranges $0.4-0.6 \mathrm{eV} .^{35}$ This fact is highlighted in Fig. $2 \mathrm{~b}$, where $R_{\mathrm{p}}$, together with $R_{\mathrm{HF}}, R_{\mathrm{LF}}$ and $R_{\mathrm{LLF}}$ electrode contributions at $700{ }^{\circ} \mathrm{C}$ are plotted for both electrodes. The highest resistances values are found for $\mathrm{LF}$ processes and, thus, the electrode performance is limited by LF processes, classically related to electrode surface steps. ${ }^{22,23}$

$R_{\mathrm{p}}$ values of $6.04 \Omega \mathrm{cm}^{2}$ and $18.9 \Omega \mathrm{cm}^{2}$ were achieved at $700{ }^{\circ} \mathrm{C}$ for LSM/BCZY27 50/50 vol\% and 60/40 vol\% composite, respectively. The slight change in $E_{\mathrm{a}}$ of the composite $60 / 40$ can be ascribed to the change in the predominant $\mathrm{BCZY}$ transport, from a protonic conductor below $700{ }^{\circ} \mathrm{C}$ to a mixed protonic/oxide-ionic conductor above this temperature. ${ }^{36}$

\subsection{Catalytic activation of LSM/BCZY27 electrodes}

The LSM/BCZY composite electrodes present electronic and protonic percolation networks. As LSM is a pure electronic conductor and possesses negligible oxide-ion conductivity, the risk of confined water formation at the electrode-electrolyte interface and consequent electrode delamination is minimized. a)

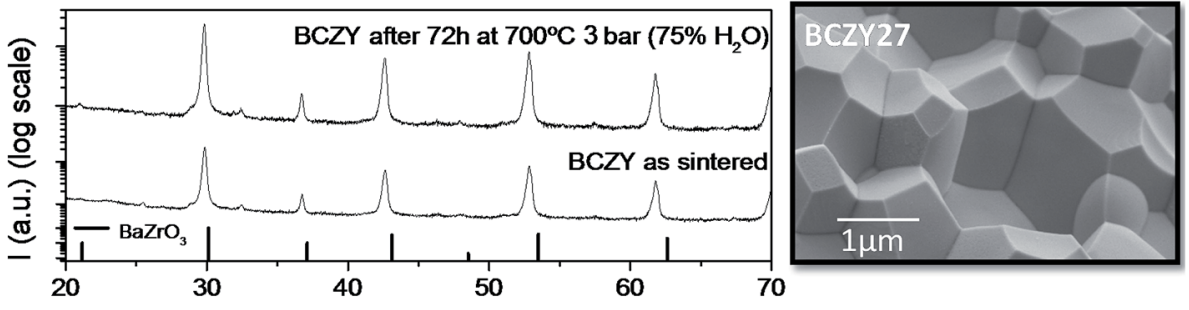

c)

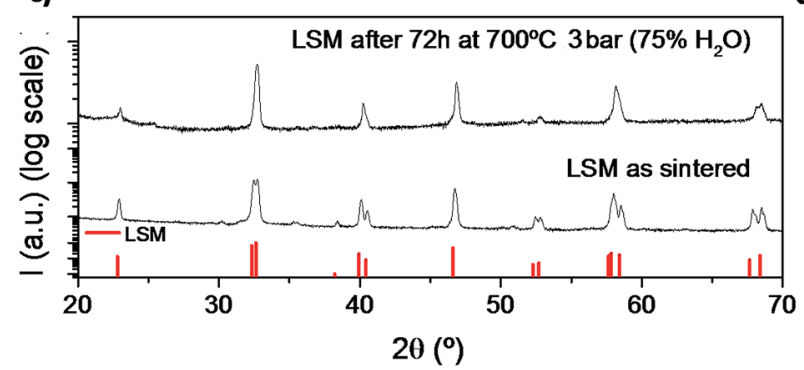

b)

d)

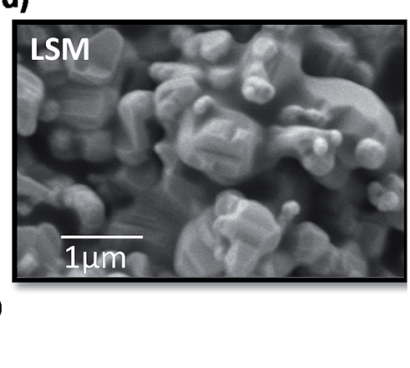

Fig. 1 XRD patterns and SEM micrographs of the ( $a$ and b) BCZY27 and (c and d) LSM after being $72 \mathrm{~h}$ at $700^{\circ} \mathrm{C}$ under 3 bar total pressure ( $p$ Air $=$ 0.75 bar and $\mathrm{pH}_{2} \mathrm{O}=2.75$ bar). 

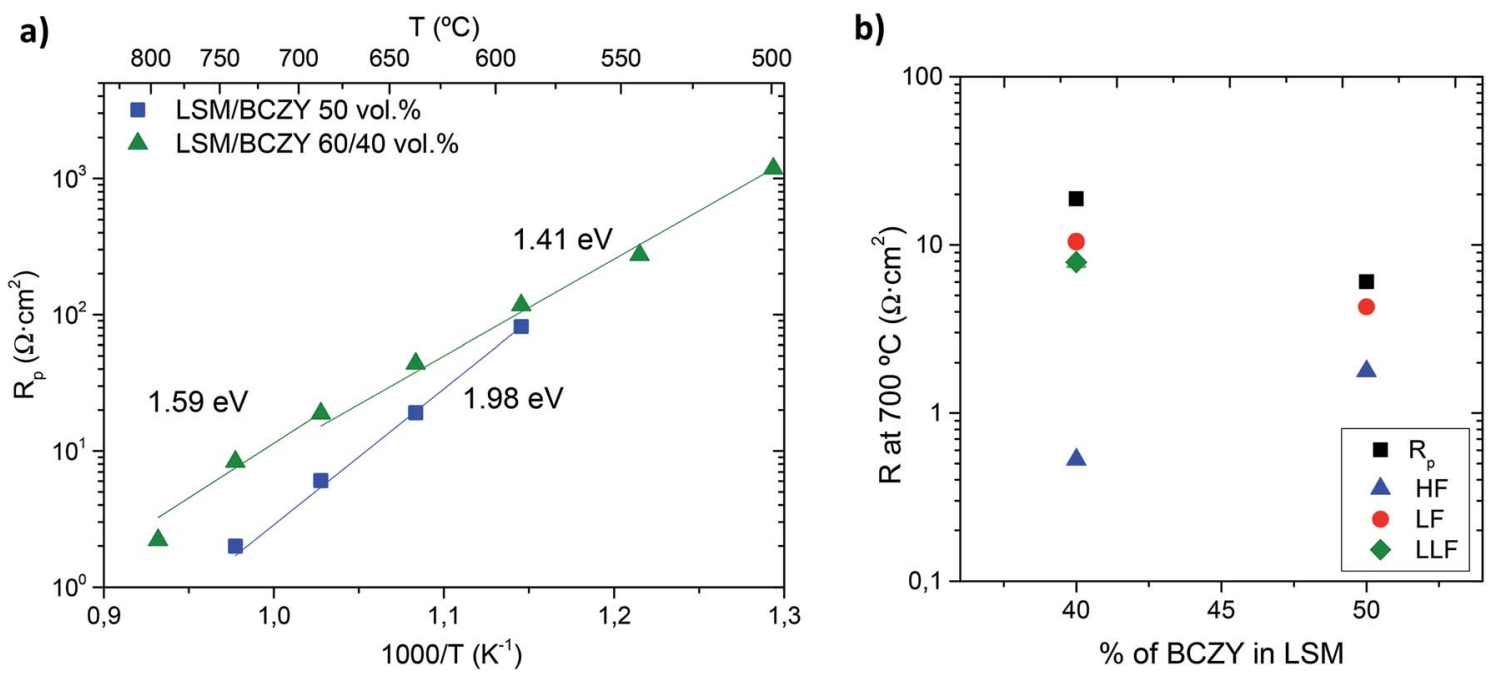

Fig. 2 (a) Temperature dependence of $R_{\mathrm{p}}$ for LSM/BCZY tested electrodes with different phase compositions and (b) $R_{\mathrm{p}}$ and $R_{\mathrm{LF}}$ and $R_{\mathrm{HF}}$ contributions measured at $700{ }^{\circ} \mathrm{C}$ as a function of the vol\% of BCZY protonic phase introduced in the LSM electrode.

The electrode layers were infiltrated by dropping an aqueous solution of different metal cations on each side of the electrolyte to improve the catalytic activity, thanks to the formation of $\mathrm{CeO}_{2}, \mathrm{Pr}_{6} \mathrm{O}_{11}, \mathrm{Pr}_{6} \mathrm{O}_{11}-\mathrm{CeO}_{2}$ and $\mathrm{ZrO}_{2}$ nanoparticles. The infiltrated cells were fired at $850{ }^{\circ} \mathrm{C}$ for $2 \mathrm{~h}$ to obtain the desired crystalline oxide phase of each one. The electrochemical performances of different anodes based on infiltrated LSM/ BCZY were analyzed in terms of polarization resistance $\left(R_{\mathrm{p}}\right)$ as a function of temperature (Fig. 3).

Fig. 3 shows the $R_{\mathrm{p}}$ as a function of temperature for LSM/ BCZY 50/50 electrode and LSM/BCZY 60/40 vol\% composite and different infiltrations: $\mathrm{Pr}_{6} \mathrm{O}_{11}-\mathrm{CeO}_{2}, \mathrm{Pr}_{6} \mathrm{O}_{11}, \mathrm{ZrO}_{2}$ and $\mathrm{CeO}_{2}$. The thermal behaviour of the four infiltrated electrodes was similar

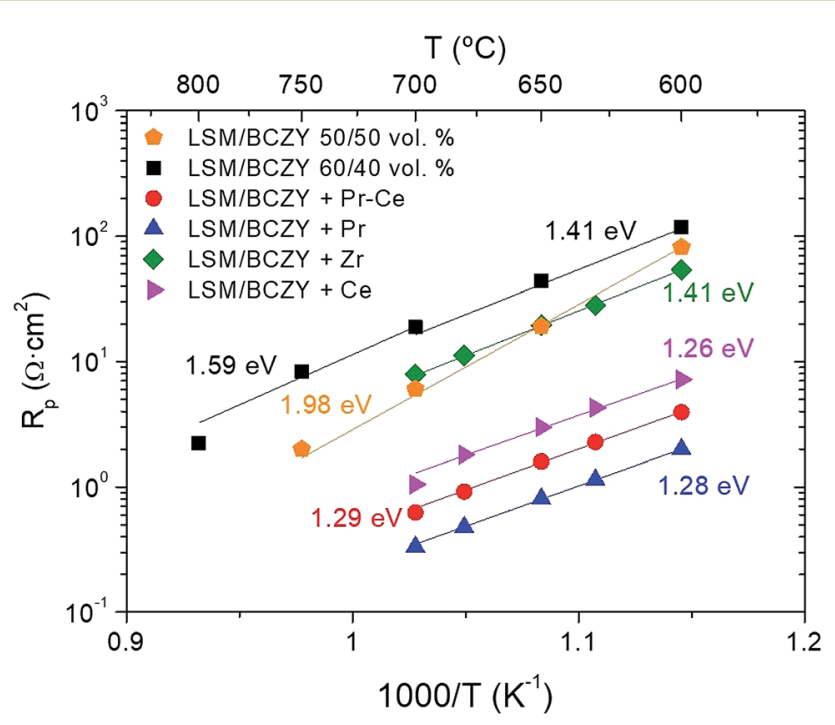

Fig. $3 R_{\mathrm{p}}$ as a function of temperature and 3 bar total pressure $(p A$ ir $=$ 0.75 bar and $p \mathrm{H}_{2} \mathrm{O}=2.75$ bar) for LSM/BCZY 50 vol\% and 60/40 vol\% backbone and LSM/BCZY 60/40 vol\% infiltrated with $\operatorname{Pr}_{6} \mathrm{O}_{11}, \mathrm{CeO}_{2}$, $\mathrm{Pr}_{6} \mathrm{O}_{11}-\mathrm{CeO}_{2}$ and $\mathrm{ZrO}_{2}$. The infiltrations were heated to $850{ }^{\circ} \mathrm{C}$. and the best performance was observed for the $\operatorname{Pr}_{6} \mathrm{O}_{11}$ infiltration in LSM/BCZY $60 / 40$ vol\% electrode with a $R_{\mathrm{p}}$ of $0.33 \Omega \mathrm{cm}^{2}$ at $700{ }^{\circ} \mathrm{C}$ and the worst performance was obtained for the $\mathrm{ZrO}_{2}$ infiltration. Furthermore, $R_{\mathrm{p}}$ increases with the introduction of more electronic phase (LSM in backbone) and the performance was improved by nanoparticle infiltration. $\mathrm{Pr}_{6} \mathrm{O}_{11}$ is a wellknown catalyst for oxygen activation in SOFC cathodes and oxygen transport membranes. ${ }^{29,37}$

Although the best performance is achieved for the LSM/ BCZY 50/50 vol\% electrode, the infiltrations were performed into the LSM/BCZY $60 / 40 \mathrm{vol} \%$ backbone since this composite exhibited better adherence on the electrolyte of tubular cells.

The effect in the cell performance of the different nanoparticles was further studied. EIS spectra (Nyquist and Bode plots) of the backbone and the infiltrated electrodes are shown in Fig. 4. From these figures, two different contributions can be distinguished for the $\mathrm{Pr}_{6} \mathrm{O}_{11}-\mathrm{CeO}_{2}, \mathrm{CeO}_{2}$ and $\mathrm{ZrO}_{2}$ infiltrated electrodes. One corresponds to LF $(0.1-1 \mathrm{~Hz})$ and the other one appears at $\mathrm{HF}(1-10 \mathrm{kHz})$. On the other hand, the spectra of $\operatorname{Pr}_{6} \mathrm{O}_{11}$ can be deconvoluted into one arc, that is, medium frequency (MF, $100 \mathrm{~Hz}$ ), which reflects the outstanding improvement of LF processes ascribed to surface steps. The non-infiltrated composite is strongly limited by LF processes, since the LF arc is much larger than the one shown at HF that remains unchanged (Fig. 4b). The addition of catalytically-active nanoparticles in the LSM/LBCZY composite can principally improve the resistance at $\mathrm{LF}$, which is attributed to (i) the intrinsic activity of the new reaction sites and (ii) the increase in the TPB length that increases the number of active sites for the electrochemical reaction..$^{22}$

Furthermore, the stability of all infiltrated anodes was also tested under a total pressure of $3 \mathrm{bar}\left(p \mathrm{Air}=0.75\right.$ bar and $p \mathrm{H}_{2} \mathrm{O}=$ $2.75 \mathrm{bar}$ ) at $700^{\circ} \mathrm{C}$ for more than 15 hours. A very slight change in the $R_{\mathrm{p}}$ values is obtained for $\operatorname{Pr}_{6} \mathrm{O}_{11}-\mathrm{CeO}_{2}$ and $\operatorname{Pr}_{6} \mathrm{O}_{11}$-infiltrated electrodes, which confirms the stability of the nanosized catalysts during the measured time. Otherwise, the performance of cell 
a)

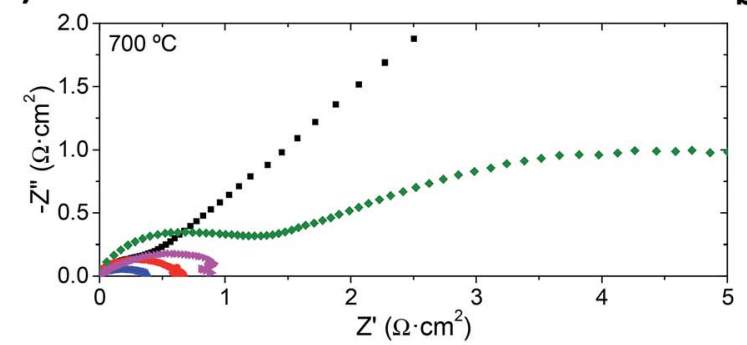

b)

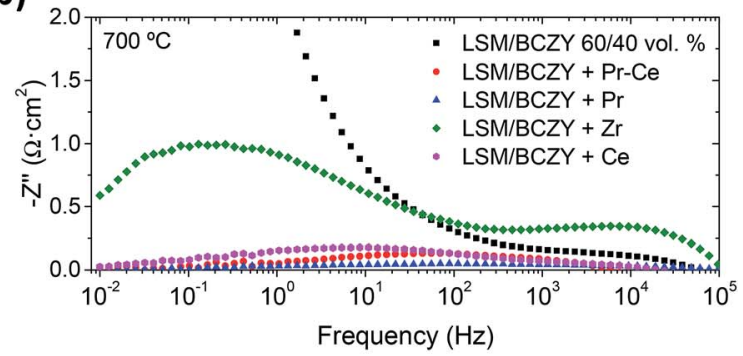

c)

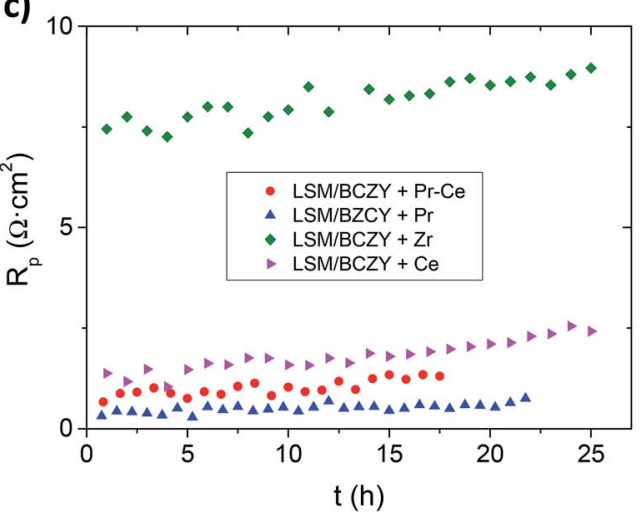

Fig. 4 (a) Nyquist, (b) Bode and (c) stability tests plots of $\mathrm{LSM} / \mathrm{BCZY} 60 / 40$ vol\% infiltrated with different catalytic nanoparticles $\left(\mathrm{Pr}_{6} \mathrm{O}_{11}-\mathrm{CeO} \mathrm{O}_{2}\right.$ $\mathrm{Pr}_{6} \mathrm{O}_{11}, \mathrm{ZrO}_{2}$ and $\mathrm{CeO}_{2}$ ) at $700{ }^{\circ} \mathrm{C}$ and 3 bar total pressure ( $p$ Air $=0.75$ bar and $p \mathrm{H}_{2} \mathrm{O}=2.75$ bar).

with $\mathrm{CeO}_{2}$ and $\mathrm{ZrO}_{2}$-infiltrated anodes deteriorate with time, i.e., the nanoparticles (size, morphology and surface chemistry) evolve with time and the reached equilibrium state has lower electrochemical activity. For this reason, both electrodes are not further considered in the following this study.

\subsection{Limiting steps in LSM/BCZY27-based electrodes}

Electrochemical impedance spectroscopy enables to get further light into the limiting steps in the anode performance. As it was described by Peng et $a .^{38}$ for fuel cells working with proton conductor electrolytes, the resistance $\left(R_{\mathrm{i}}\right)$ is proportional to the oxygen partial pressure $\left(p \mathrm{O}_{2}\right)$ and steam partial pressure $\left(p \mathrm{H}_{2} \mathrm{O}\right)$ by the $m$ and $n$ parameters, respectively, by the following relation:

$$
R_{\mathrm{i}} \propto p \mathrm{O}_{2}{ }^{-m_{\mathrm{i}}} p \mathrm{H}_{2} \mathrm{O}^{-n_{\mathrm{i}}}
$$

The value of $m$ and $n$ are determined by the elementary steps as follows:

Fig. 5 represents the isothermal analysis of $R_{\mathrm{HF}}, R_{\mathrm{LF}}$ and $R_{\mathrm{LLF}}$ for the LSM/BCZY 60/40 vol\% backbone electrode and the $\mathrm{Pr}_{6} \mathrm{O}_{11}-\mathrm{CeO}_{2}$-infiltrated electrode as a function of (1) $p \mathrm{O}_{2}$ at
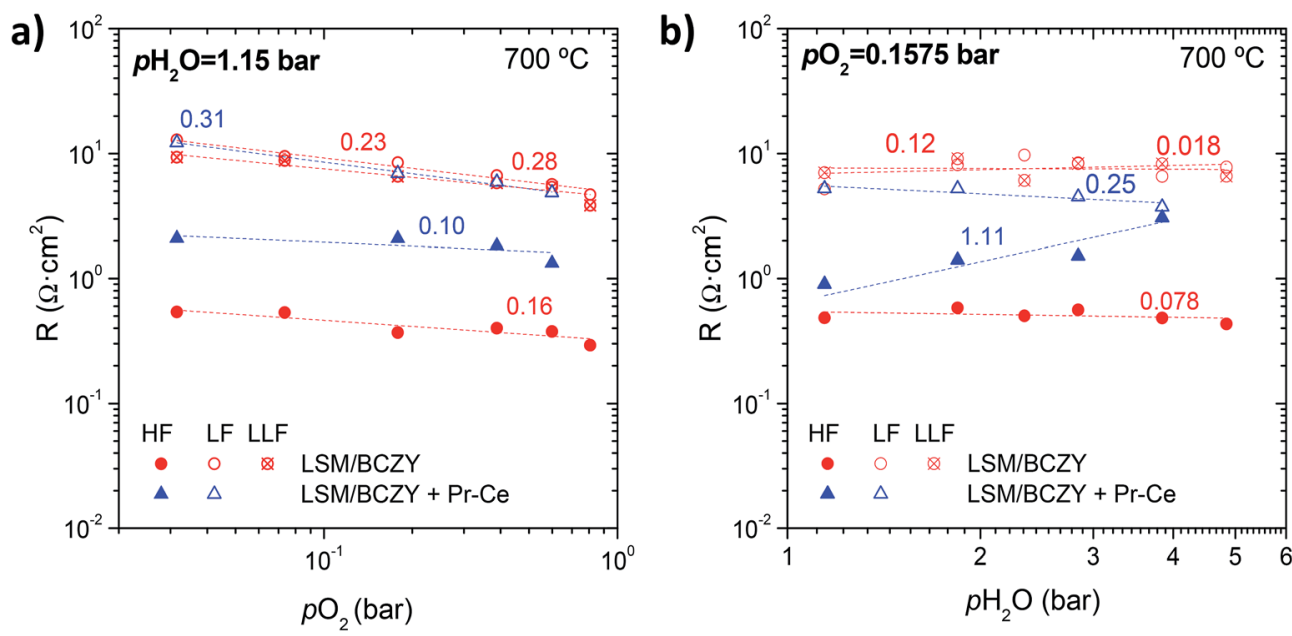

Fig. $5 R_{\mathrm{p}}$ and HF, LF and LLF contributions of LSM/BCZY27 60/40 vol\% at $700{ }^{\circ} \mathrm{C}$ as a function of (a) $p \mathrm{O}_{2}$ at constant $p \mathrm{H}_{2} \mathrm{O} \sim 1.15$ bar and (b) $p \mathrm{H}_{2} \mathrm{O}$ at constant $\mathrm{pO}_{2} \sim 0.1575$ bar. 
Table 1 Elementary anode reaction steps and their order with respect to oxygen partial pressure $(m)$ and steam partial pressure $(n)$

\begin{tabular}{llll}
\hline & Elementary reaction steps & $m_{\mathrm{i}}$ & $n_{\mathrm{i}}$ \\
\hline Step 1 & $\mathrm{H}_{2} \mathrm{O}_{(\mathrm{g})} \rightarrow \mathrm{H}_{2} \mathrm{O}_{(\mathrm{TPB})}$ & 0 & 1 \\
Step 2 & $\mathrm{H}_{2} \mathrm{O}_{(\mathrm{TPB})} \rightarrow \mathrm{OH}_{(\mathrm{TPB})}{ }^{-}+\mathrm{H}_{(\mathrm{TPB})}{ }^{+}$ & 0 & 1 \\
Step 3 & $\mathrm{OH}_{(\mathrm{TPB})}{ }^{-} \rightarrow \mathrm{H}_{(\mathrm{TPB})}{ }^{+}+\mathrm{O}_{(\mathrm{TPB})}{ }^{-}$ & 0 & $1 / 2$ \\
Step 4 & $\mathrm{H}_{(\mathrm{TPB})}{ }^{-} \rightarrow \mathrm{H}_{(\mathrm{bulk})}{ }^{-}$ & 0 & $1 / 2$ \\
Step 5 & $\mathrm{O}_{(\mathrm{TPB})}{ }^{-} \rightarrow \mathrm{O}_{(\mathrm{TPB})}{ }^{-}+\mathrm{e}^{-}$ & 0 & 0 \\
Step 6 & $\mathrm{O}_{(\mathrm{TPB})}{ }^{-} \rightarrow \mathrm{O}_{(\mathrm{ad})}{ }^{-}$ & $1 / 4$ & 0 \\
Step 7 & $\mathrm{O}_{(\mathrm{ad})}{ }^{-} \rightarrow \mathrm{O}_{(\mathrm{ad})}+\mathrm{e}^{-}$ & $3 / 8$ & 0 \\
Step 8 & $\mathrm{O}_{2(\mathrm{ad})} \rightarrow \mathrm{O}_{2(\mathrm{~g})}$ & 1 & 0
\end{tabular}

constant $p \mathrm{H}_{2} \mathrm{O} \sim 1.15$ bar and (2) $p \mathrm{H}_{2} \mathrm{O}$ at constant $p \mathrm{O}_{2} \sim 0.1575$ bar. $R_{\mathrm{LF}}$ and $R_{\mathrm{LLF}}$ for both electrodes decrease with increasing $p \mathrm{O}_{2}$ whereas $R_{\mathrm{HF}}$, remains constant. On the other hand, the three resistance contributions for the backbone at constant $p \mathrm{O}_{2}$ remain unchanged while for the infiltrated anode, $R_{\mathrm{LF}}$ decreases and $R_{\mathrm{HF}}$ increases with increasing the $p \mathrm{H}_{2} \mathrm{O}$.

The values inside the Fig. $5 \mathrm{a}$ and $\mathrm{b}$ are the $m$ and $n$ parameters and are calculated from fitting the power law $R_{\mathrm{i}} \propto$ $p \mathrm{O}_{2}{ }^{-m_{\mathrm{i}}} p \mathrm{H}_{2} \mathrm{O}^{-n_{\mathrm{i}}}$ (absolute values), providing information about the species involved in the oxygen reduction reaction. The polarization resistance, the associated capacitances and the relaxation frequencies for the different contribution in both electrodes are available in ESI (ESI Fig. S4 and S5, $\uparrow$ respectively). Table 2 summarizes the $m$ and $n$ values obtained for each resistance contribution.

Thus, the polarization resistance and the corresponding resistance contributions of the backbone and the infiltrated electrode depend on $\mathrm{pO}_{2}$ and $p \mathrm{H}_{2} \mathrm{O}$ as follows:

Backbone:

$$
R_{\mathrm{p}} \propto \mathrm{pO}_{2}^{1 / 4} \mathrm{pH}_{2} \mathrm{O}^{0}
$$

Table $2 m$ and $n$ values from fitting of $R_{\mathrm{i}} \propto \mathrm{pO}_{2}{ }^{-m_{i}} \mathrm{pH}_{2} \mathrm{O}^{-n_{\mathrm{i}}}$ and related capacitances

\begin{tabular}{|c|c|c|c|c|c|c|}
\hline & \multicolumn{2}{|l|}{$m$} & \multicolumn{2}{|l|}{$n$} & \multicolumn{2}{|c|}{ Related capacitance $\left(\mathrm{F} \mathrm{cm}^{-2}\right)$} \\
\hline & Backbone & $\begin{array}{l}\text { Backbone }+ \\
\operatorname{Pr}_{6} \mathrm{O}_{11}-\mathrm{CeO}_{2}\end{array}$ & Backbone & $\begin{array}{l}\text { Backbone }+ \\
\operatorname{Pr}_{6} \mathrm{O}_{11}-\mathrm{CeO}_{2}\end{array}$ & Backbone & Backbone $+\operatorname{Pr}_{6} \mathrm{O}_{11}-\mathrm{CeO}_{2}$ \\
\hline$R_{\mathrm{p}}$ & 0.25 & 0.27 & 0.048 & 0.044 & - & - \\
\hline$R_{\mathrm{HF}}$ & 0.16 & 0.10 & 0.078 & 1.11 & $(1.3-2.4) \times 10^{-4}$ & $(1.8-2.8) \times 10^{-4}$ \\
\hline$R_{\mathrm{LF}}$ & 0.28 & 0.31 & 0.12 & 0.25 & $(0.8-1.1) \times 10^{-1}$ & $(2.6-6.5) \times 10^{-3}$ \\
\hline
\end{tabular}

a)

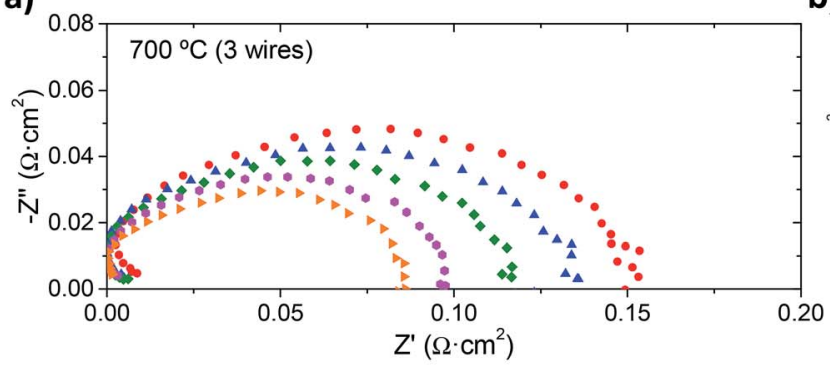

c)

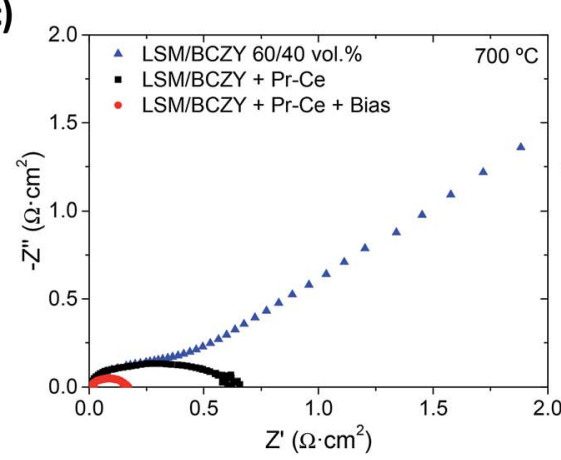

d)

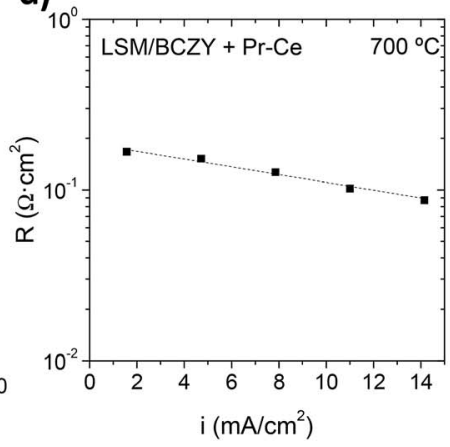

b)

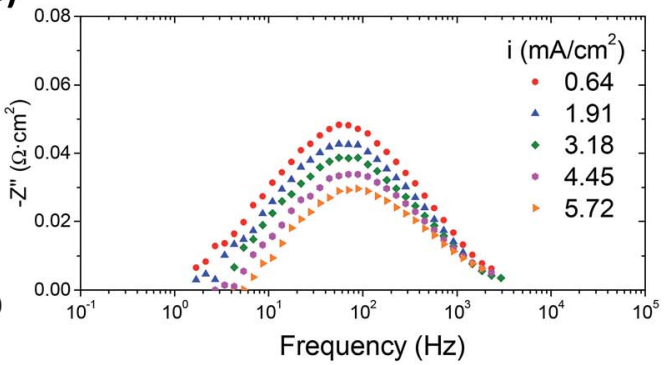

e)

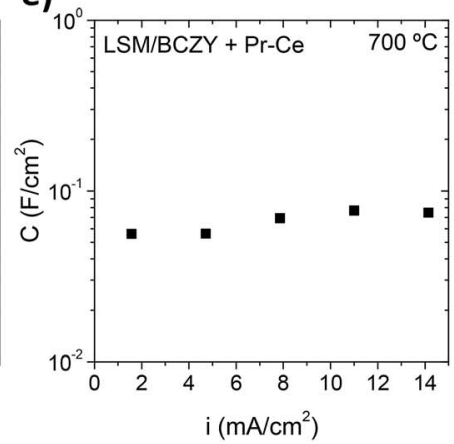

Fig. 6 Effect of imposed current on composite electrodes: (a) Nyquist and (b) Bode plots of $\mathrm{LSM} / \mathrm{BCZY}^{60 / 40}$ vol\% infiltrated with $\mathrm{Pr}_{6} \mathrm{O}_{11}-\mathrm{CeO}_{2}$ at $700{ }^{\circ} \mathrm{C}$. (c) Nyquist plot at $700{ }^{\circ} \mathrm{C}$ and 3 bar total pressure ( $p$ Air $=0.75$ bar and $p \mathrm{H}_{2} \mathrm{O}=2.75$ bar) of the: LSM/BCZY backbone, the $\mathrm{Pr}_{6} \mathrm{O}_{11}-$ $\mathrm{CeO}_{2}$-infiltrated electrode and with an applied current density of $0.64 \mathrm{~mA} \mathrm{~cm}^{-2}$. (d) LF resistance contribution and (e) capacitance as a function of the applied current. 


$$
\begin{gathered}
R_{\mathrm{HF}} \propto p \mathrm{O}_{2}{ }^{1 / 6} p \mathrm{H}_{2} \mathrm{O}^{0} \\
R_{\mathrm{LF}} \propto p \mathrm{O}_{2}{ }^{1 / 4} p \mathrm{H}_{2} \mathrm{O}^{1 / 8} \\
R_{\mathrm{LLF}} \propto p \mathrm{O}_{2}{ }^{1 / 4} p \mathrm{H}_{2} \mathrm{O}^{0}
\end{gathered}
$$

Infiltrated:

$$
\begin{gathered}
R_{\mathrm{p}} \propto p \mathrm{O}_{2}{ }^{1 / 4} p \mathrm{H}_{2} \mathrm{O}^{0} \\
R_{\mathrm{HF}} \propto p \mathrm{O}_{2}{ }^{1 / 10} p \mathrm{H}_{2} \mathrm{O}^{1} \\
R_{\mathrm{LF}} \propto p \mathrm{O}_{2}{ }^{3 / 8} p \mathrm{H}_{2} \mathrm{O}^{1 / 4}
\end{gathered}
$$

As seen in Table 1, Step 6 has the same $R_{\mathrm{LLF}}$ dependence on $p \mathrm{O}_{2}$ and $p \mathrm{H}_{2} \mathrm{O}$, suggesting that the LLF arc for the backbone electrode may correspond to the diffusion of $\mathrm{O}_{\mathrm{TPB}}{ }^{-}$. The activation energy of $R_{\mathrm{LLF}}$ was determined to be $1.20 \mathrm{eV}$ (see ESI Fig. S6 $\dagger$ ) which is in the range of oxygen diffusion and supports the limitation of $\mathrm{O}_{\mathrm{ad}}{ }^{-}$ diffusion. For $R_{\mathrm{LF}}$, the $p \mathrm{H}_{2} \mathrm{O}$ order $(n)$ found is close to $1 / 8$ and suggests that a combination of steps associated to transport of proton and oxygen species is limiting. The activation energy for $R_{\mathrm{LF}}$ is $1.35 \mathrm{eV}$, approximately. For $R_{\mathrm{HF}}$, however, Step 6 might be the corresponding step and the exponent respect to $\mathrm{pO}_{2}$ is close to $1 / 6$, which considers the effect in p-type conduction of oxide-ion transport. The activation energy associated to $R_{\mathrm{HF}}$ is $1.28 \mathrm{eV}$.

On the other hand, taking into account Fig. 5 (fitted $n$ and $m$ parameters) and the power laws depicted in eqn (6)-(8), for the $\mathrm{Pr}_{6} \mathrm{O}_{11}-\mathrm{CeO}_{2}$-activated electrode, the $\mathrm{OO}_{2}$ reaction orders $(m)$ are close to $1 / 10$ and $3 / 8$ for $R_{\mathrm{HF}}$ and $R_{\mathrm{LF}}$ and $p \mathrm{H}_{2} \mathrm{O}$ orders $(n)$ are 1 and $1 / 4$, respectively. The rate limiting processes might be assigned to the water splitting and the transport of ionic species (Steps 1 and 2) (HF) and the oxidation of $\mathrm{O}_{\mathrm{ad}}{ }^{-}$to $\mathrm{O}_{\mathrm{ad}}(\mathrm{LF})$ while

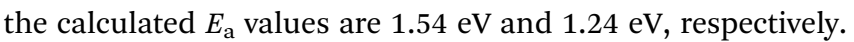

\subsection{Effect of applied current}

Fig. 6a and b (Nyquist and Bode plots) illustrate the positive effect of the imposed current on the performance of one activated electrode. Specifically, LSM/BCZY 60/40 vol\% electrode infiltrated with $\mathrm{Pr}_{6} \mathrm{O}_{11}-\mathrm{CeO}_{2}$ and treated at $850{ }^{\circ} \mathrm{C}-$ prior to test - was characterized in a three-wire configuration applying different currents. This configuration consists of one working electrode (WE) on one anode, with the corresponding sensing contact on the electrolyte (SE) and enables to measure only one anode contribution. A range of currents $\left(1.57-14.15 \mathrm{~mA} \mathrm{~cm}^{-2}\right)$ is imposed in this study.

Fig. 6c shows that the $R_{\mathrm{p}}\left(0.087 \Omega \mathrm{cm}^{2}\right)$ of the infiltrated electrode when a current is applied $\left(1.57 \mathrm{~mA} \mathrm{~cm}^{-2}\right)$ is much lower than under OCV. The frequencies for these impedance spectra are available in ESI Fig. S7. $\dagger$ Fig. $6 d$ indicates, in this case, there is only one resistance contribution $\left(R_{\mathrm{LF}}\right)$ associated with the electrode process which decreases with increasing current density, as can be quantitatively proven by equivalent circuit modelling with a capacitance between $10^{-2}$ to $10^{-1} \mathrm{~F}$ $\mathrm{cm}^{-2}$ (Fig. 6e). This fact can be related to the activation of the dissociative adsorption and diffusion of oxygen.
The Nyquist plots of the remaining catalytic infiltrations $\left(\mathrm{Pr}_{6} \mathrm{O}_{11}, \mathrm{CeO}_{2}\right.$ and $\mathrm{ZrO}_{2}$ ) at $700{ }^{\circ} \mathrm{C}$ and 3 bar total pressure ( $p$ Air $=0.75$ bar and $p \mathrm{H}_{2} \mathrm{O}=2.75$ bar) applying a current density of $1.57 \mathrm{~mA} \mathrm{~cm}^{-2}$ are plotted in Fig. 7a-c. The results show that $R_{\mathrm{p}}$

a)

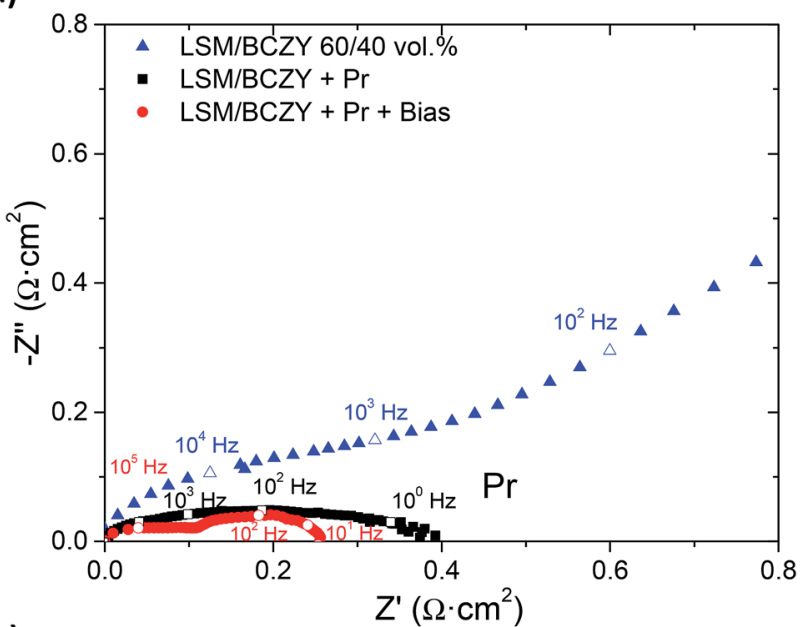

b)

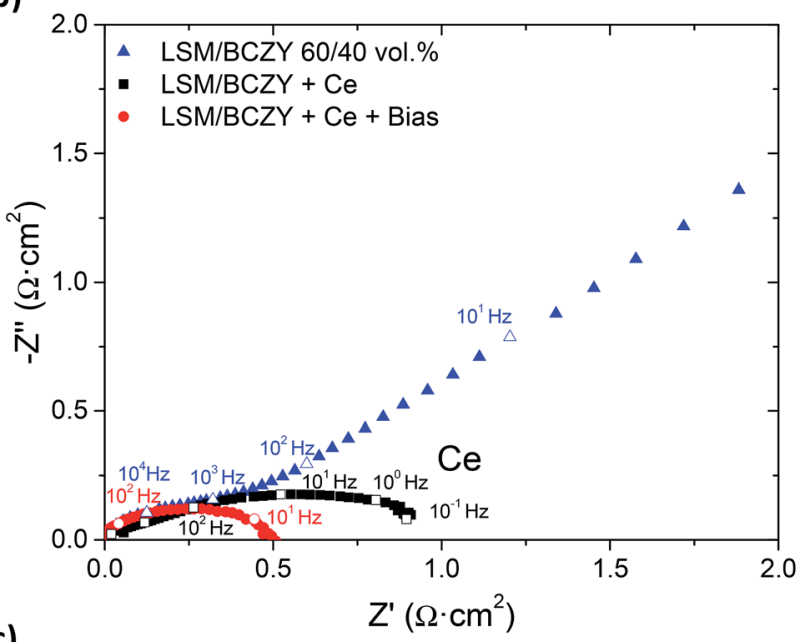

c)

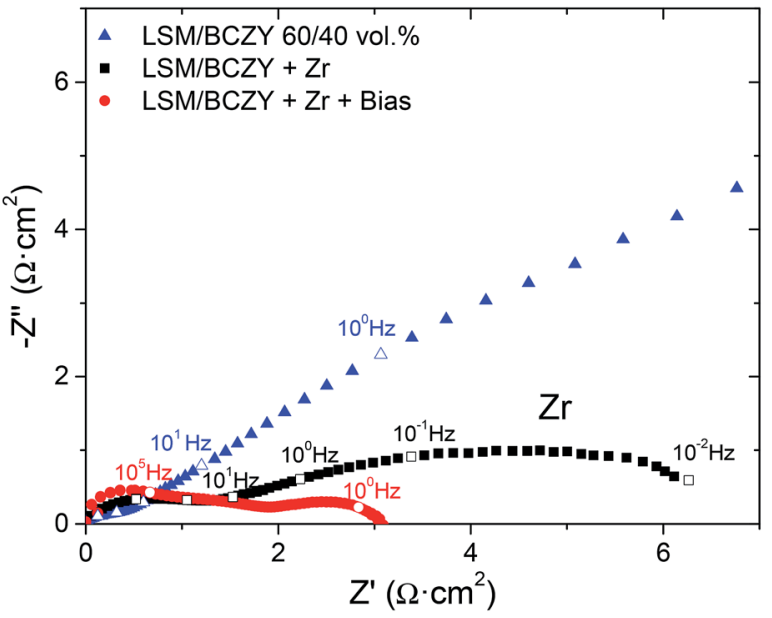

Fig. 7 Nyquist plot at $700{ }^{\circ} \mathrm{C}$ and 3 bar total pressure ( $p$ Air $=0.75$ bar and $p \mathrm{H}_{2} \mathrm{O}=2.75$ bar) of LSM/BCZY $60 / 40$ vol\% backbone electrode and infiltrated with different catalytic nanoparticles applying $0.63 \mathrm{~A}$ $\mathrm{cm}^{-2}$ of current density: (a) $\operatorname{Pr}_{6} \mathrm{O}_{11}$; (b) $\mathrm{CeO}_{2}$ and (c) $\mathrm{ZrO}_{2}$. 
a)

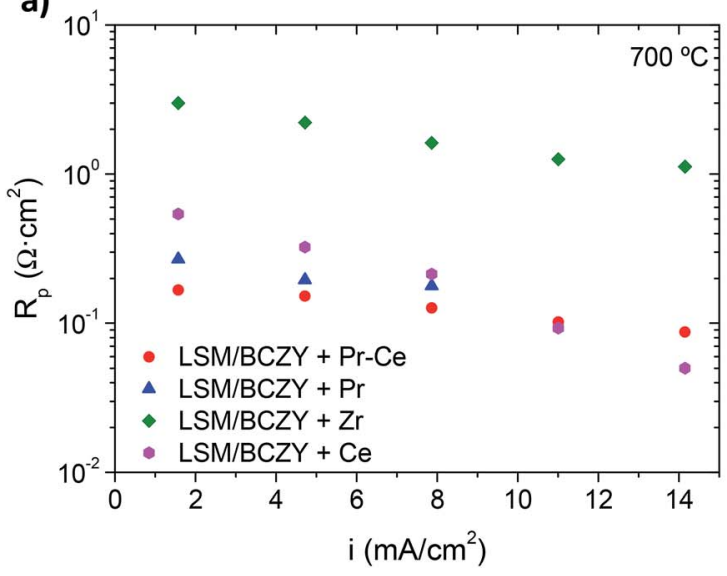

b)

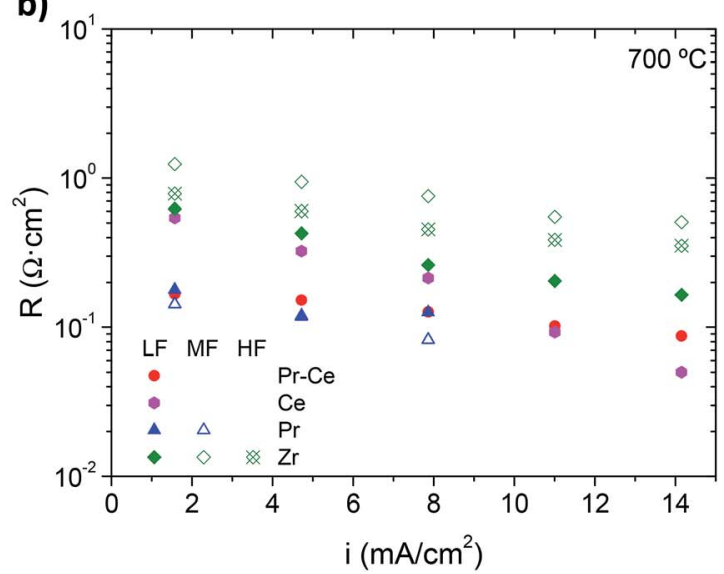

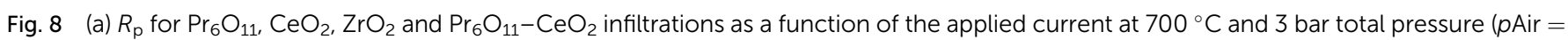
0.75 bar and $\mathrm{pH}_{2} \mathrm{O}=2.75$ bar) and (b) $\mathrm{HF}, \mathrm{MF}$ and LF resistances.

values of $\mathrm{Pr}_{6} \mathrm{O}_{11}, \mathrm{CeO}_{2}$ and $\mathrm{ZrO}_{2}$ infiltrated electrodes are 0.27, 0.54 and $3.3 \Omega \mathrm{cm}^{2}$ at $700{ }^{\circ} \mathrm{C}$, respectively.

The electrode infiltrated with $\mathrm{CeO}_{2}$ shows the lowest $R_{\mathrm{p}}$ $\left(\sim 0.05 \Omega \mathrm{cm}^{2}\right.$ at $\left.700{ }^{\circ} \mathrm{C}\right)$ under bias $\left(14.15 \mathrm{~mA} \mathrm{~cm}^{-2}\right)$ and it is even better than $\mathrm{Pr}_{6} \mathrm{O}_{11}-\mathrm{CeO}_{2}$-infiltrated electrode Fig. 7a. However, in the overall current range (1.57-14.15 $\mathrm{mA} \mathrm{cm}^{-2}$ ) $\mathrm{Pr}_{6} \mathrm{O}_{11}-\mathrm{CeO}_{2}$-infiltrated electrode performs better. Note that polarization resistance for this electrode undergoes a less sharp drop with the imposed currents. The origin of the distinct electrochemical activation might be related to the different redox state, i.e. oxidation state, of the catalyst cations associated to the reaction sites involved in the adsorption and charge transfer among the different electrolysis surface species.

The electrode processes for the four infiltrated electrodes are distinguished by equivalent circuit modelling. Fig. $8 \mathrm{~b}$ shows the resistance contributions $\left(R_{\mathrm{HF}}, R_{\mathrm{MF}}\right.$ and $\left.R_{\mathrm{LF}}\right)$ as a function of the applied current density while the associated capacitance and relaxation frequency are plot in ESI Fig. S8. $\dagger$ $\mathrm{Pr}_{6} \mathrm{O}_{11}-\mathrm{CeO}_{2}$ and $\mathrm{CeO}_{2}$-infiltrated electrodes exhibit only one resistance contribution at LF $\left(R_{\mathrm{LF}}\right)$ whereas $\operatorname{Pr}_{6} \mathrm{O}_{11}$-infiltrated electrode presents two $\left(R_{\mathrm{LF}}\right.$ and $\left.R_{\mathrm{MF}}\right)$. On the other hand, $\mathrm{ZrO}_{2}$ infiltrated electrode shows three contributions $\left(R_{\mathrm{LF}}, R_{\mathrm{MF}}\right.$ and $R_{\mathrm{HF}}$ ), as it has without imposing a current through the electrode. In most cases, the catalyst addition into the electrode produces a positive effect on electrode behaviour, i.e. (1) the activation energy is decreased and (2) the polarization resistance can be further improved by imposing a net current. In the particular case of $\mathrm{ZrO}_{2}$-infiltrated electrode, only a minor promoting effect is detected and its operation is controlled by the resistive processes at MF and HF.

\subsection{Post-mortem cell characterization}

In order to complete this work, the best symmetrical infiltrated cell was characterized by means of XRD after operation under electrolysis conditions under 3 bar total pressure ( $p$ Air $=0.75$ bar and $p \mathrm{H}_{2} \mathrm{O}=2.75$ bar). Fig. 9a shows the XRD patterns of the LSM/BCZY 60/40 vol\% infiltrated with $\operatorname{Pr}_{6} \mathrm{O}_{11^{-}}$
$\mathrm{CeO}_{2}$, where the diffraction peaks for $\operatorname{Pr}_{6} \mathrm{O}_{11}$ and $\mathrm{CeO}_{2}$ phases are present whilst no other phases can be detected in the backbone. This is also highlighted through the analysis of the electrode microstructure in the fracture cross-section of the symmetrical cell (Fig. 9b-d). SEM analysis of the fracture cross-section of LSM/BCZY 60/40 vol\% electrode infiltrated with $\operatorname{Pr}_{6} \mathrm{O}_{11}-\mathrm{CeO}_{2}$ reveals that the backbone electrode is covered by needle-like crystals corresponding to the $\operatorname{Pr}_{6} \mathrm{O}_{11}$ (highlighted in green, Fig. 9d) and round nanoparticles related
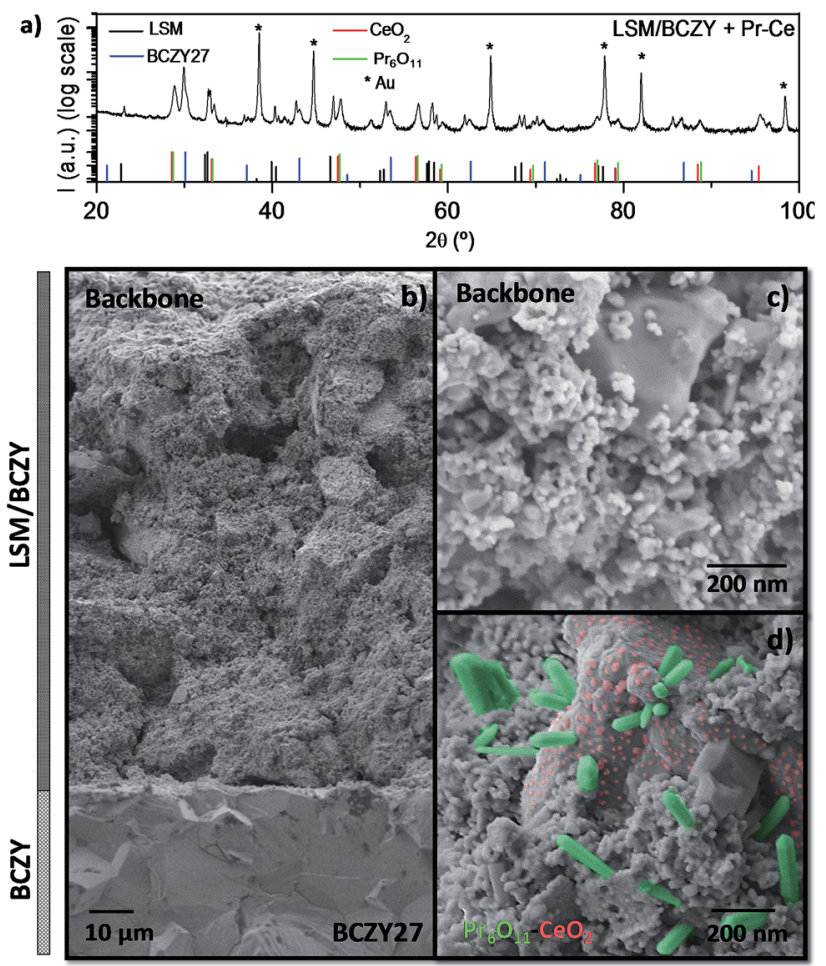

Fig. 9 (a) XRD pattern of the LSM/BCZY 60/40 vol\% infiltrated with $\mathrm{Pr}_{6} \mathrm{O}_{11}-\mathrm{CeO}_{2}$ after operating conditions 3 bar total pressure ( $p$ Air = 0.75 bar and $p_{2} \mathrm{O}=2.75$ bar). SEM micrographs of broken surfaces in cross-section view: (b) LSM/BCZY 60/40 vol\% electrolyzer, (c and d) LSM/BCZY 60/40 vol\% backbone electrode and LSM/BCZY 60/ 40 vol\% infiltrated with $\operatorname{Pr}_{6} \mathrm{O}_{11}-\mathrm{CeO}_{2}$. 
to the $\mathrm{CeO}_{2}$ (in red, Fig. 9d). Moreover, the infiltrated electrode does not show degradation in the anode after operation and presents a good dispersion of the catalytic nanoparticles in the anode.

\section{Conclusions}

The infiltration of different catalytically-activated nanoparticles into a steam electrode based on LSM/BCZY27 backbone enabled to strongly reduce the electrode polarization resistance $\left(R_{\mathrm{p}}\right)$ towards water splitting and oxygen evolution under operation at high steam pressures (up to 5 bar). The best electrochemical performance for the $60 / 40 \mathrm{vol} \%$ backbone at $700{ }^{\circ} \mathrm{C}$ and 3 bar of steam and air ( 0.75 bar of air and 2.25 bar of steam) is the $\operatorname{Pr}_{6} \mathrm{O}_{11}$-infiltrated electrode $\left(0.33 \Omega \mathrm{cm}^{2}\right)$. In addition, the electrode performance can be further enhanced by imposing a current being the $\mathrm{Pr}_{6} \mathrm{O}_{11}-\mathrm{CeO}_{2}$-infiltrated electrode that achieve the best performance in this work.

On the other hand, the effect of both $p \mathrm{O}_{2}(0.03-0.81$ bar $)$ and $p \mathrm{H}_{2} \mathrm{O}$ (1.14-4.84 bar) was analyzed on the polarization resistance and contributions of LSM/BCZY 60/40 vol\% and $\mathrm{Pr}_{6} \mathrm{O}_{11^{-}}$ $\mathrm{CeO}_{2}$-infiltrated electrode. Increasing $p \mathrm{O}_{2}$ leads to a slight increase in the electrode $R_{\mathrm{p}}$ whereas increasing $p \mathrm{H}_{2} \mathrm{O}$ gives rise to a reduction in $R_{\mathrm{p}}$. The results demonstrate that addition of $\mathrm{Pr}_{6} \mathrm{O}_{11}-\mathrm{CeO}_{2}$ nanoparticles into steam electrodes for high steam pressures is a promising route to enhance the anode performance for proton ceramic electrolyzer cells.

\section{Conflicts of interest}

There are no conflicts to declare.

\section{Acknowledgements}

Financial support by the Spanish Government (Grants SEV2016-0683, RTI2018-102161 and ENE2014-57651), Generalitat Valenciana (PROMETEO/2018/006) and by the EU through FP7 Electra Project (Grant Agreement 621244) is gratefully acknowledged. The support of the microscopy service at Universitat Politècnica de València (UPV) for the SEM analysis is recognized.

\section{References}

1 H. Iwahara, Solid State Ionics, 1995, 77, 289-298.

2 H. Iwahara, Y. Asakura, K. Katahira and M. Tanaka, Solid State Ionics, 2004, 168, 299-310.

3 S. Escolástico, C. Solís and J. M. Serra, Int. J. Hydrogen Energy, 2011, 36, 11946-11954.

4 C. Solís, V. B. Vert, M. Fabuel and J. M. Serra, J. Power Sources, 2011, 196, 9220-9227.

5 C. Solís, L. Navarrete, S. Roitsch and J. M. Serra, J. Mater. Chem., 2012, 22, 16051-16059.

6 S. Escolastico, C. Solis, C. Kjolseth and J. M. Serra, Energy Environ. Sci., 2014, 7, 3736-3746.

7 H. Malerød-Fjeld, D. Clark, I. Yuste-Tirados, R. Zanón, D. Catalán-Martinez, D. Beeaff, S. H. Morejudo,
P. K. Vestre, T. Norby, R. Haugsrud, J. M. Serra and C. Kjølseth, Nat. Energy, 2017, 2, 923-931.

8 S. H. Morejudo, R. Zanón, S. Escolástico, I. Yuste-Tirados, H. Malerød-Fjeld, P. K. Vestre, W. G. Coors, A. Martínez, T. Norby, J. M. Serra and C. Kjølseth, Science, 2016, 353, 563-566.

9 S. Hossain, A. M. Abdalla, S. N. B. Jamain, J. H. Zaini and A. K. Azad, Renewable Sustainable Energy Rev., 2017, 79, 750-764.

10 K. Leonard, Y. Okuyama, Y. Takamura, Y.-S. Lee, K. Miyazaki, M. E. Ivanova, W. A. Meulenberg and H. Matsumoto, J. Mater. Chem. A, 2018, 6, 19113-19124.

11 R. Zohourian, R. Merkle, G. Raimondi and J. Maier, Adv. Funct. Mater., 2018, 28, 1801241.

12 J. M. Serra, Nat. Energy, 2019, 4, 178-179.

13 C. Duan, J. Tong, M. Shang, S. Nikodemski, M. Sanders, S. Ricote, A. Almansoori and R. O'Hayre, Science, 2015, 349, 1321-1326.

14 S. Choi, C. J. Kucharczyk, Y. Liang, X. Zhang, I. Takeuchi, H.-I. Ji and S. M. Haile, Nat. Energy, 2018, 3, 202-210.

15 E. Fabbri, S. Licoccia, E. Traversa and E. D. Wachsman, Fuel Cells, 2009, 9, 128-138.

16 V. B. Vert, C. Solis and J. M. Serra, Fuel Cells, 2011, 11, 81-90. 17 E. Perry Murray and S. A. Barnett, Solid State Ionics, 2001, 143, 265-273.

18 R. Strandbakke, V. A. Cherepanov, A. Y. Zuev, D. S. Tsvetkov, C. Argirusis, G. Sourkouni, S. Prunte and T. Norby, Solid State Ionics, 2015, 278, 120-132.

19 Y. Gan, J. Zhang, Y. Li, S. Li, K. Xie and J. T. S. Irvine, J. Electrochem. Soc., 2012, 159, F763-F767.

20 N. Bausá, C. Solís, R. Strandbakke and J. M. Serra, Solid State Ionics, 2017, 306, 62-68.

21 Z. Liu, M. F. Liu, L. Yang and M. L. Liu, J. Energy Chem., 2013, 22, 555-559.

22 C. Solis, L. Navarrete, F. Bozza, N. Bonanos and J. M. Serra, ChemElectroChem, 2015, 2, 1106-1110.

23 C. Solis, L. Navarrete, S. Roitsch and J. M. Serra, J. Mater. Chem., 2012, 22, 16051-16059.

24 H. P. Ding, N. P. Sullivan and S. Ricote, Solid State Ionics, 2017, 306, 97-103.

25 M. Dippon, S. M. Babiniec, H. P. Ding, S. Ricote and N. P. Sullivan, Solid State Ionics, 2016, 286, 117-121.

26 K. Leonard, Y. Okuyama, Y. Takamura, Y. S. Lee, K. Miyazaki, M. E. Ivanova, W. A. Meulenberg and H. Matsumoto, J. Mater. Chem. A, 2018, 6, 19113-19124.

27 M. J. Jørgensen and M. Mogensen, J. Electrochem. Soc., 2001, 148, A433-A442.

28 J. Garcia-Fayos, R. Ruhl, L. Navarrete, H. J. M. Bouwmeester and J. M. Serra, J. Mater. Chem. A, 2018, 6, 1201-1209.

29 L. Navarrete, C. Solis and J. M. Serra, J. Mater. Chem. A, 2015, 3, 16440-16444.

30 S. M. Babiniec, S. Ricote and N. P. Sullivan, J. Electrochem. Soc., 2014, 161, F717-F723.

31 W. Li, B. Guan, L. Ma, S. Hu, N. Zhang and X. Liu, J. Mater. Chem. A, 2018, 6, 18057-18066.

32 R. Strandbakke, E. Vøllestad, S. A. Robinson, M.-L. Fontaine and T. Norby, J. Electrochem. Soc., 2017, 164, F196-F202. 
33 P. Babilo and S. M. Haile, J. Am. Ceram. Soc., 2005, 88, 23622368.

34 E. Rebollo, C. Mortalo, S. Escolastico, S. Boldrini, S. Barison, J. M. Serra and M. Fabrizio, Energy Environ. Sci., 2015, 8, 3675-3686.

35 E. Fabbri, L. Bi, D. Pergolesi and E. Traversa, Energy Environ. Sci., 2011, 4, 4984-4993.
36 S. Ricote, N. Bonanos, H. J. Wang and R. Haugsrud, Solid State Ionics, 2011, 185, 11-17.

37 J. Garcia-Fayos, R. Ruhl, L. Navarrete, H. J. M. Bouwmeester and J. M. Serra, J. Mater. Chem. A, 2018, 6, 1201-1209.

38 F. He, T. Wu, R. Peng and C. Xia, J. Power Sources, 2009, 194, 263-268. 